\title{
THE CRISIS OF SELF- INSECURITY OF MODERN MAN IN PINTER'S
}

\section{THE ROOM}

\author{
Assist Instructor Ienas Talib Naseef \\ University of Baghdad, College of Education for Women \\ Department of English
}

DOI: $10.37648 /$ ijrssh.v10i02.017

Received:14 ${ }^{\text {th }}$ February, 2020; Accepted:04 ${ }^{\text {th }}$ March, 2020; Published: 18th March, 2020

\begin{abstract}
:
Harold Pinter is one of the major dramatists who deals with the existential problems of modern man who lives in a hostile universe. Moreover, Pinter's writings show a special talent, he invented a new form of themes such as the aimlessness of man, the nameless menace and the difficulty of verification of existence. Pinter succeeds in shedding light on the dilemma of obliterated characters who are unable to feel their own existence in his play The Room. They feel exhausted and frustrated in a world that deprives them from their human identity. These feelings turn them into a senseless people, unable to build bridges of understanding and communication between themselves and others or even within themselves. Consequently, those characters find security and shelter in their withdrawal from society and living in limited space. Pinter depicts the suffering of the modern man'scondition associated with the feeling of loneliness and horror throughout his characters in his play The Room. At first sight these characters seem ordinary people, but in fact they are restricted by a mysterious fear and horror which lead them into an atmosphere of expectation and suspense and finally their inevitable self-defeat.
\end{abstract}

Keywords: Harold Pinter, The Room, fear and horror, modern man, human identity. 
The power of self-identity within the modern man is a milestone in most of Harold Pinter's plays. Pinter is the prominent modern dramatist who successfully portrays the crisis of human identity in his works. He focuses on the depiction of the dilemma of men's struggling to find a place in a decomposition world. Besides, they do not feel their own worth or their importance in society. Pinter's characters live in a harsh and merciless world which offers them no opportunity to prove their humanity and identity. Therefore, they retract from this world and from any active participation in society and live a lonely life. As Pinter expresses this idea through his theater "strives to express its sense of senselessness of the human condition and the inadequacy of the rational approach by the open abandonment of rational devices and discursive thought".(Bennett and Carson, 2012, p.171)

Pinter's plays belong to a kind of drama which is called "the kitchen sinks"(Wilson G. Knight, 1963, p.48.) this drama sheds lights on the hidden zones of human psych which is called instincts or the unconscious mind. It also deals with the problems and secrets of human existence. As an Absurdist, he raises the important issue of the existentialist security, lack of communication, undefined fear, alienation and the lack of meaning in life in his play The Room. As Martin Esslin points that "Pinter shared with the absurdist the same interest in the presentation of the essential problems of existence, death, and alienation". Pinter presents his motif of man's request for his existence and identity in a world fills with fragments and social confusion throughout his characters. As Pinter's points out that "his main focus is on the characters' at the extreme edge of their living, where they are living pretty much alone". (Walter Wager, 1969, p.136).Bert, the husband, is a fifty years old, Rose, the wife, is the central character. She is a simple- minded woman; she is older than her husband almost sixty. In this play this couple lives in isolation and the human's dilemma is clear from the very beginning of this play.
Throughout the setting of The Room, Pinter illustrated his theme of alienation, self-identity and a special atmosphere of mystery. The mysterious world of terror in his play is always created in a single room. In Pinter's works the room represents the modern world and the complicated life which is brought by the industrial revolution. It stands for the radical changes in society from a simple rural life into a very harsh and highly restrictive life. As Joseph Sherman points out: "The room occurs again and again in Pinter's subsequent work as a powerful symbol of his obsession with safety and security and the dangerous of dispossession". (Joseph Sherman, 1970.p.110).

The play begins with two people in a room struggling with the continuous flow of fear, anxiety and nameless threats. Pinter presents a kind of strange feeling of fear that surrounded everyone inside the room. The basic situation of this play is a room with a door, and the outside where is cold. The room is warm and light, while the outside world is dark and hostile, for these, it is so frightening and complicated world.

I don't know why you have to go out. .

It'll be dark in a minute as well, soon. It gets dark now" — and to cold. (The

Room, p.93)

Pinter is as a realistic playwright in his writing, he follows the realistic approach of clinical analysis of the human condition in reflecting the dilemma of modern man whose self-integrity has been threaten by external pressures. As Ruby Cohn points" Most crucial to an understanding of Pinter's theater is the symbolism of his character. For all their initially realistic appearance, their cumulative impact embraces the whole of humanity." (Ruby Cohn, p. 80)

Notoriously, What Pinter's achieve as a dramatist is his rigorous portraying of man's despairing attempt to face the disorder within themselves and the universe. There are certain resemblances between the 
sufferings of Pinter's characters and these modern men. They try to structure their lives, but unaware that their behavior and actions are constantly confronted by chaos. This chaos is the disorder of self not the universe because Pinter's characters do not occupy themselves about finding an order in a disorder universe.

As Pinter's characters, modern man growing in a world fills with uncertainty feels uprooted. He is unable to cling to any thought that can help and support him to face his blemishes. As Esslin points that the "the core of Pinter's works as a dramatist lies essentially in portraying man's fear and presenting it as something real, ordinary, and acceptable as everyday occurrence without giving this fear any abstraction or a surrealistic aspect.(Martin Esslin, 1961, p. 235). Rose and Bert like many modern men, are suffering from loneliness and alienation within themselves and their community. Their feeling of alienation and homelessness is caused by their discovering of the futility and enigma of their search for identity. Pinter's works introduce a world of "seeming inconsequentiality, tangential communication, dislocated relationships, and undefined threats." (Andrew Sanders, 2004, p. 621)

Because of his absurdity, Pinter's character should face two alternatives fate: either they remain in their rooms and play their routine of living to avoid the onslaught of forces they can not question, or despite their efforts to the contrary, they may be met head on by these vicious forces. For this, Pinter's characters are unable to maintain a balance between their internal integrity and the external world with all its demands, responsibilities and pressures." In his plays Pinter portrays the horrible state of modern man through linking the mysterious horror and absurdity. In a universe that is suddenly deprived of illusions and of light, man feels a stranger. His is an irremediable exile.... This divorce between man and his life....., truly constitutes the feeling of Absurdity". (Abrams, p. 1)

One of the most important characteristics of Pinter's drama is the daily ritual which structures his plays. His plays portray the daily habitual activities which became empty of meaning and an automatic way of coping with life. At the beginning of the play, Rose seems busy in preparing food for her husband, and continuously speaks, Bert remains silent. The breakfast ritual is an attempt to protect her life with her husband against any outsider danger, it is unspoken fear of unnamed danger. She is talking to her husband without any answering from him, she says,

"It's very cold out. I can tell you.

It's murder. (The Room, p.95)

It seems that Rose's attempts to fill her husband with warmth when he goes outside the room to ensure not being cold is not the real reason. In fact her behavior is to fill the extinct features in their characters and to hide their spiritual poverty, modern men have recourse to certain behaviors by which they try to find an offset for many things that they lack. One of these substitutes is their over concern with silly matters, such as foods, newspapers, and etc. These are their defenses in which they hide their fears and emotional frustrations just like Rose and Bert in Pinter's play. Pesta says: "The Room can also be understood as a psycho-drama in which the room itself presents the island of conscious security afloat upon a dark sea of forgotten memories and vague wishes. Pinter renders the apartment building as Kafka might: impossibly large, so the landlord, if he is the landlord, no longer remembers how many floors it has. On this level of psychological symbolism, Riley's emergence from the basement may represent the rising of an unconscious impulse in Rose to return to heaven of true security."(John Pesta, 1967, p.125.)

Rose hopes that she can live in peace with her husband in their room. She says that her aim is to "keep the cold out."It seems that she is worried from something that bothers their safety shelter as she states: "And we're not bothered. And nobody bothers us." Moreover, they adhere to their rooms and trying desperately to protect themselves against any outer dangers because these rooms represents kind of 
shelters in which they hide themselves from the outer world. People usually "cling on with ferocious tenacity to their few belongings, particularly their rooms"' (Martin Esslin, 1976, p.108)

The security in their room becomes ephemeral and vulnerable with the coming of intruders to these shelters. For those characters "the room is the sacred garment" that surrounds all human anxieties and fears. The room like a womb, it represents the most secure place in human life. Their feeling of security is tenuousbecause some extrinsic powers threaten to intrude their lives and deprive them of this feeling of insecurity and alienation. These intruding persons are representative of some mysterious powers that are indefinable and over than the characters' abilities to face them. This will lead them to their destruction and final defeat." (Lois Gordon, 2001, p.96)

The intruder who look as a victimizer in fact seems to be mirrors reflecting victims' own visualization and subdued feelings. When any destruction occurs to the victim, it is due to the enactment of his own hidden violence. Therefore, the menacing figures are Pinter's techniques for leading his characters into exposing themselves. Consequently, they are shaken violently by these pressures and instead of facing them they avoid acknowledging their presence. Instead of fighting back any difficulty that may confront, they resort themselves to some unhealthy ways such as degradation as defenses against difficulties and pressures.

As it previously mentioned, Rose talks all the time and Bert never participate in the conversation and remaining silent. By talking incessantly, she is "giving herself the reassurance which he refuses to give to her."(Ronald Hayman, 1975, p. II). Rose tries to impose certain demands on their relationship. At the same time, by refusing to make the responses that would meet the demands of Rose's language, Bert refuses to confirm that their relationship is as Rose wants it to be. In The Room Pinter explores "potential constraints imposed upon the individual when he comes into contact with other individuals." (Austin Quigley, 1975), p.79)

However, the person who is exposed to such constrains in a given situation can sometimes balance them by looking for some compensation that the person finds indispensable. Moreover, what creates irony in this play is that the character becomes a member in relationships which acknowledge and affirm that individuality in order to substantiate his sense of his individuality. Yet, his relationship with other people makes him confront their complementary demands. The two parts in this relationship try to look for compromise. If they fail in creating such compromise, the result is tension and conflict become the dominant elements in their relationship.

Bert just sits there, reads his paper and allows himself to be fed and pampered. He never utters a word. Rose seems to be married to a man, but that is by no means certain since Pinter manages to maintain ambiguity around his characters. Rose seems very anxious to please Bert and to make herself as useful and agreeable to him as possible. This couple presents a motif which can be found in Pinter's other plays which is the male- female relationship where man is always cold, silence and passive, the women motherly, nagging, fussy and talkative. According to Pinter points of view the dilemma of modern man occurs due to the lack of communication between the characters.

Pinter elucidates another portion of seclusion of modern man through Bert's relation with his van. It is a unique one, throughout his description of his van Bert evokes a kind of sexual images in the audience's minds. Bert used to treat the van as his women and this indicate the loneliness of man in the modern society. Bert comments: "I drove her down hard ... Then I drove her back, hard. I sped her. I caned her along."She was good. Then, I got back ... she was good. She went with me. "She don't mix it with me. I use my hand I get hold of her. I go where I go. She took me there. She brought me back". (The Room, p. 32) 
All the time Rose wants Bert to play the role of one dependent on her motherly supervision. He simply refuses to participate in a conversation that defines their relationship in this way. In fact, it is not only Bert refused to acknowledge Rose's demands, but Rose's also refuses to acknowledge Bert's silence. She continues to talk as if he was participating in her conversation on terms she decides. Rose for example, talks partly to fill the silence, but mainly to "record, reiterate, and reshape those components of her existence that give her life a meaning she can value. As Simon Trussler argues that" all talk and the cozy cups of tea are hopeless gesture of defiance against a brooding nemesis."(Simon Trussler, 1973, p.32)

Psychiatrists argue that every human self must have its uniqueness and individuality which passes through a process of maturation. But, some of Pinter's characters are preventing from being mature. They are prevented from feeling that, as a result, they regress to a childlike state making them unable to perform their roles in life being heavily dependent on others. There is a friction between them, he never tells her to be quiet and she never demands his replies. There is a discord in their relationship. This discord is not acknowledged by their character, but it is clear in every detail in their relationship. The main reason of this discord is Rose's refusal to treat Bert as an equal partner in their marital relationship because he is a silent man who lets his wife mother him. Although, Rose seems anxious about Bert's food and very devoted to serve him in the best way possible, but she gives little, if no interest at all to his human needs such as respect and independency. She treats him like a little boy telling him what he thinks and feels as if she knows better than him. Her existence is "centered on his but in effect she is denying him the right or the ability to exist independently". Ibid. (Ronald Hayman, 1975), p .II)

She is undermining his confidence in his own emotional reactions and his own perception of reality. This is what Ronald Laing calls "schizophrenogenic"Ibid,(Ronald Hayman, 1975, p.
II) which means she wants to dominate the man to make him follow her routine. In fact, she constructs "a wall of words and weary routine"(Baker \& Tabachnick, 1973, p.26) around herself and her husband and she wants him to submit to her influence, although she pretends not to mind whether he goes out:

Still, I 'm much better today. I don't know about you though.

I don't know whether you ought to go out. I mean you shouldn't.

Straight after you've been laid up. Still. Don't worry, Bert. You go.

(The Room, p.102)

Although their relationship lacks harmony, yet they cannot leave each other, Rose and Bert find roles for themselves to play in this restricted life. In fact what makes them stay together is the feeling of an undefined source. Her relationship with her husband provides her with a feeling of security and worth, similar to the security she feels in her room. Bert may give her security feelings but he never satisfies her personal emotional feelings. Rose, in many occasions expresses her feelings of comfort and satisfaction that she lives in the room they share:

We're happy up here. It's not far up either, when you come

In from outside. And we're not bothered. And nobody bothers us.

(The Room, p.103)

In fact, her speech raises the possibility of her doubts as well as her reasons for overcoming those doubts. Moreover, she is also not trying to convince her husband but she is trying to convince herself. Her words indicates the impression that she and her husband share the same satisfaction. In addition her repeating the same conversation several times means a confirmation of the increasing of her inner doubts.

Like most of Pinter's women, Rose plays a complicated game to ensure her safety. She is the 
wife-mother, not only to Bert but to the other men who enter her room. She infantilizes, emasculates, and plays the coquette. Mr. Kidd, the landlord, seems willing to converse with Rose. Her one sided and complex speech of her silent husband is now replaced by a normal form of conversation. But instead of becoming clearer, the problem and ambiguity increase. Mr. Kidd's readiness to speak is like the silence of Bert. It serves only to increase the uncertainties of Rose's world. As Martin Esslin argues that: "there is nothing intrinsically improbable or unreal in an old man who is so dotty that he talks nonsense. And, yet, very characteristically already, by an accumulation of such basically, realistic details, Pinter succeeds in building up an atmosphere of menace, of Kafkaesque uncertainty. (Martin Esslin, 1977, p.61)

His talks is like Bert's silence, it is considered as a defiance against Rose's attempt to dominate him. Their conversation becomes like a battle over who can claim or suggest knowledge of the other's life in a threatening area. Her attempt to dominate Mr. Kidd parallels her excessive mothering of Bert. Rose's attempts to dominate men are the result of the insecurity and fear she feels within herself.

"Mr. Sands: The man in the basement said there was one. One room. Number seven he said.

Pause.

Rose: That's this room.

Mr. Sands: We'd better go and get hold of the landlord.

Mrs. Sands: Well, thank you for the warm-up, Mrs Hudd. I feel better now.

Rose: This room is occupied.

Mr. Sands: Come on.

Mrs. Sands: Goodnight, Mrs. Hudd. I hope your husband won't be too long. Must be lonely for you, being all alone here.(The Room. P.108)

The invasion of the room represents "a state of inaction that involves the denial of some aspects of existence" (Arthur Ganz, 1972, p.13) which is the central action in each of Pinter's play. To portray the precariousness of man's existential security, Pinter employs the usurper, a menacing figure who actively undermines the existence of other characters. The entry of the Sands is important because they symbolize the intrusion of the outer world into the secure room which the old couple inhabits by claiming it vacant. They carry the darkness and coldness into Rose's shelter. Their presence is important because it provides another married couple with whom to compare and contrast Rose and Bert. Unlike Rose and Bert who have reached a fixed state of mal-adjustment, the Sands are constantly in the process of establishing their relationship.

What adds to her fear is her meeting with the Sands. The young couple comes looking for a room to be let. They tell her that they meet a man in the basement who informs them that Rose's room is to be let. Although Rose feels frightened because of her unexpected meeting with the Sands just outside her room, she reveals few suspicions about them and she invites them in. This supports the point that she is not holding tight to her room as a refuge and an escape from the outside world. She is always struggling to reconcile her fear and insecurity to the ever present curiosity that she feels toward people outside and people in the basement emphasize her interest in what lies beyond the room.

Here, the function of the room is like a container of man's emotions, false hope and fear which man could not escape. Therefore, man is deprived from every sense of fertility and life. Actually, the people who live in that room have some feelings and attitudes that give them a special emotional identity. These characters stay in their rooms because of their feelings of fear or as a result of their facing previous experience which were difficult. It is obvious that the importance of the room is derived from its being a representative of the human mind. In other words Pinter used the room as a means of reflecting the state of mind.

"If they ever ask you, Bert, I'm quite happy where I am" (The Room. P.93) .The room for Rose does not only represent a bedroom which contains a few pieces of furniture, but it is the place that has 
defined her life structure, an extension of her personality, and to protect her sense of self.

"No this room's all right for me.

I mean, you know where you are. (The Room, p. 92).

It seems that Rose and Bert succeed in building an order and secure for themselves, yet they cannot stop fearing from the outside world. In addition, their isolation in that room represents an escape from the outside cruel world. Rose's dreams about her role in this life are linked with her evaluating to the room. Thus, the merits of the room are highly praised by referring to the disadvantage of living in the basement or by contrasting the warmth and light inside with the dark and cold outside.

Pinter's characters are generally unable to create a personal sense of identity. They are not living peacefully and harmoniously in their environment. They are exposed to external pressure that threatens their psyche. Unlike, normal people who can build up defenses to fight the external forces internal equilibrium. His character are violently shaken by the external pressure which leave them weak and baffled. The outside is always unknown to the characters in Pinter's play. It is full of menace and horror. In fact the characters always struggle for a living space in which they feel content as long as they live safely in that space. Their fear arouse when they feel that there is something threatens their safety, something unknown and undefinable. The atmosphere of mystery is a clear significance of Pinter's drama.

In fact the Sands are not the only source of threat that intrudes in Rose's life, but there is another one. After the explicit denial of Rose's existence another quick visit from Mr. Kidd who begins to show his cruel intentions when he tells her that there is a blind Negro in the basement waiting to see her and he will not leave without seeing her. According to some critics the Negro is a personification of uncertainty and coldness which threaten Rose's security and identity. The conflict in Pinter's play occurs when "one of the outsiders' forces penetrates into the room and threaten the security of its occupants". (George E Wellworth, 1971, p.225). This conversation with Mr. Kidd increases her fears of a mysterious danger. Rose's conflicts arises whether or not to meet that man.

Rose's safety is shaken when she first meets the Negro. These intruders succeed in bringing her face to face with her reality and past. The Negro represents a symbol of lurking and subconscious violence and the threat that imposed on Rose. As George Wellworth points: "The Negro may symbolize death, the woman's past, or some hidden guilt complex- probably the last one."(Ibid. p. 227). The coldness of the basement in which the Negro lives represents his cruel intentions towards Rose. Her continuous confirmation of the inferiority of the basement and the hostility of the outside world resembles her belief that the inside world is a pleasant one. In fact, the precise nature of her guilt is uncertain, but it seems that it has to do with an early experience with her father. She identifies the Negro with her father and she acts out the initial incestuous relationship. Either real or fantastic that led her essentially to behave in the way she does.

At first, Rose's with unconscious feelings refuses to meet that man. She behaves as a loyal wife as she states" Do you expect me to see someone I don't know? With my husband not her?"(The Room, p.117) at the same time her fears increase when she thinks that the Negro might visit her when her husband is at home. This ensure that there is a kind of uncertainly in her personality. This duality in her character makes her vulnerable. Rose now is in a dilemma, if she accepts meeting the man or refuses to see him. The presence of the visitor seems to be a threatening to her and this is an indication of her betrayal of Bert. Riley's "the Negro" presence becomes the central points of both her fear and curiosity. On one hand, he confirms her fear of coldness and darkness in the outside world. On the other hand he justifies her curiosity about possibility of unknown presence in the mysterious basement. 
The appearance of Riley brings to the surface the discord in the relationship between Rose and Bert. The huge gap between them which was unacknowledged before, now becomes apparent to Rose. Darkness which is associated with her suppressed life and curiosity has entered to the room in the shape of the Negro. The blind man asks Rose to leave the room and go back home.

"Riley: Your father wants you to come home.

Pause.

Rose: Home?

Riley: Yes.

Rose: Home? Go now. Come on. It's late. It's late.

[...]

Riley: Come home, Sal.

Pause.

Rose: What did you call me?

Riley: Come home, Sal.

Rose: Don't call me that.

Riley: I want you to come home.

Rose: No.

Riley: With me.

Rose: I can't. (The Room, p.124)

The name "Sal" raises many questions, who is "Rose"? Why is she escaping? And from whom? This problem does not yield to any answer because Pinter's world is built up on uncertainties and after all mess of identity is far from being a verbose technique used by Pinter's to deform his characters and to strip them of everything they own, even their names. "One of the central themes in Pinter's drama is the difficulty in verifying identity. What happened? Who, when, and where? These questions are always raised, yet they have no response on the part of Pinter who exposes the frustrations and the failure of human communications, and reveals to us in play after the separation and isolation of individual". (Barbra Kreps, 1979, p.48.)

Moreover, Pinter constantly like to bring women character in a teasing confrontation with the probably destructive power of the belligerent world outside. And when this power breaks in, it works hard to strip the characters of their identity so as to get assimilated into the world of no identity. The blind Negro calls Rose Sal, she wants him not to call her by that name and at the same time she does not refuse or deny it. It is obvious that Rose suffers from traumatic experience which throws its shadow on her present life. Pinter presents characters who seem real people having a life stretching before and after the action of the play. This sometimes leads reader and audience to analyze the character's past life. This could be something the playwright never mention in the paly but one can conclude from the way in which the character is presented by the dramatist.

It seems quite clear that Riley serves the purpose of reveling Rose's unconscious role of frailty and to show her real twisting personality. Rose's room seems to be used tohide her true character and she is trying to cover her authentic background, identity and past memories. She scars of being discovered in her peace haven, in her room. Hamedreza Kohzadi et al. reach a possible interpretation. "They propose, Rose's insistence on the security of the room has a close relation to her sense of guilt. Later when the Negro calls Rose Sal, this significance comes to reality. She has lived with Bert under one assumed name. Perhaps she has been a prostitute that has no desire to hear about. The fear of outside is a projection of Rose's inner guilt. She fears for her own being to be exposed to the other."(Hamedreza Kohzadi, 2012)

John Pesta argues that Riley seems not only threaten the security of the room, but his call regarded as a fearful call of death, as he states that:

"a call to leave a life of fearful security and gain a richer life of memory,.... and freedom by acknowledging her past, or by accepting death......, Roses father at first seems a realistic earthly figure, and later takes on the character of a symbol for the divine. Going home has traditionally represented the act of finding final Peace after a life of trials and anxieties. (John Pesta. 1972, p. 124)

At the end she lost her sight and becomes blind. "Can't see. I can't see. I can't see." (The Room. P. 
119) she comes to reality and to an awareness of her existence that has been suppressed in her unconscious for all these years. Her blindness is an indication of her defeat by the intruders who deprived her from all her defenses especially her room. "The day is a hump. I never go out."(The Room, p. 119)

Rose's loss of sight confirms, on the one hand, her fundamental link with the blind Negro and on the other hand, points to her mental deterioration. The loss of sight is a spiritual distortion rather than a physical state. Rose, who has been afflicted by blindness, is actually being crushed into non-entity along with the herald of death and nothingness which are personified in the figure of the blind Negro. In fact the Negro here symbolizes death, the wife's past, or a hidden guilt. The blind man is an externalization of the other as he has broken into the room to rob Rose of her true self or identity. In this context Esslin says:

"The blind Negro is all too manifestly a symbol, an allegory. He has been lying down below and had fore knowledge of the future. He must therefore be a being from beyond the confines of this world: a dead man or a messenger of death. His blackness and his blindness reinforce these allegorical implications. The blindness in the end belongs to the same category of symbolism that must mean her own death". (Martin Esslin, 1968. p. 66.)

In fact there was a conspiracy by Mr. Kidd and the Sands to destroy Rose and Bert's family. They used the Negro as a means to separate Rose from Bert and back Rose to her father. It is clear that Rose does not consider Riley as a stranger, at the same time she wishes to leave Bert and go with the Negro. Bert realizes that the Negro is represented a threat to his family. Katherine Burkman comments:" the women receives the blind Negro as a father and her husband stamps him to death as a.....rival."(Katherine $\mathbf{H}$. Burkman.1971. P. 71.)

Bert takes revenge and beats Riley to deathin a savage way. R.F. suggests that:" Riley is not a symbol but the real instance of extreme loneliness, of human weakness, who calls to the women, and who must be kicked to death by the man unable to face such weakness in human being." (Storch R.F. p.145)

On the other hand some critics as Katherine Burkman believes that "Bert represents Rose's true enemy not Riley. Riley could even represent her deep and buried thoughts in her unconscious ness which she always wishes to escape from. And Bert's attack on Riley is an attack on her own dreams, thoughts, and wishes to leave him". (Katherine H. Burkman, 1971. P. 72.)

The room is represented "as a microcosm of the world. In the room the people feel safe. Outside are only alien forces inside there is warmth and light".(George E Wellworth.1964, p.225). Throughout The Room, Pinter's succeeded in depiction of the inability of people to protect themselves from the outsider harm and insecurity.It shows the character difficulties to adjust themselves to the outer world. For Rose, this adjustment of the self to its environment is a process of continuous compromise. The play shows the process of characters struggling with the problems of the self in its relationship to themselves and other. It seems ordinary idea but it has a universal implication. Rose's yearning and attempt to convince herself that she has found a place where she could please all her needs was always a self- deception.

\section{CONCLUSION:}

This paper explores Pinter's tackling of the dilemma of identity, self-insecurity and existence of modern man in his play The Room. It is Pinter's typical play, what he achieves as a dramatist is his precise depiction of man's desperate attempts to face turmoil within themselves. The main issue is man's struggling against controversies which manipulate them to obliterate his own self and withdraw him from others to live in isolation. They retreat into a limited world where they look for security and protection and avoid facing reality. They find in their part to avoid facing reality. They find in their rooms 
the only refuge from outer challenges. This temporary refuge is threatened by the intrusions of people from the outer world.

Pinter is interested in the exploration of the deep, hidden and undefined states of modern man psych. Pinter's concern is man's struggling to know that ambiguous part of his being which is called self. He depicts modern man sufferings because of other's persistent attempts to deprive him from his individuality and to dehumanize him. In the final picture of the play, the playwright tries to portray the man's victimization. In almost of his plays, Pinter tends to create an atmosphere full of secrecy. He prefers the use of the proscenium, the closed framed stage where the characters can be shut up and spied on. This method seems to correspond with the characters he presents in his plays. They are reserved people who turn most of their energy to keeping themselves hidden from view as if they were in a kind of underworld. The characters live in a very limited world and cannot break out from it. Finally, the audience find themselves in an incomprehensible situation, by sharing the insecurity felt with the central character.

\section{REFERENCES:-}

- Abrams, M. H. and Geoffrey, Harpham. (2008). A Glossary of Literary Terms. $8^{\text {th }} \mathrm{ed}$. New Delhi: Cengage Learning Print.

- Baker,William \&. Tabachnick, Stephen E. (1973). Harold Pinter. Edinburgh, Oliver \& Boyd.

- Bennett, Michael Y. and Benjamin D. Carson ed, (2012). Eugene O'Neill's OneAct Plays: New Critical Perspectives. USA.

- Burkman, Katherine H. (1971). The dramatic world of Harold Pinter: Its Basic in Ritual (Colombia: Ohio state University Press.
- Cohn, Ruby, The world of Harold Pinter, in Pinter: A Collection of Critical Essays. Englewood Cliffs, N. J.: Prentice-Hall. Inc.

- Esslin, Martin, (1977). Pinter: a Study of his Plays. London: Eyre Methuen.

- Esslin, Martin,(1961). The theater of the Absurd, New York, Anchor.

- Esslin, Martin, (1968). The Theatre of the Absurd. London: Pelican Books.

- Ganz, Arthur, (1972). Introduction, in Pinter: a Collection of Critical Essay, Englewood Cliffs, N. J.: Prentice-Hall. Inc.

- Gordon, Lois ed. (2001) .Pinter at 70, A Casebook, great Britain Routledge.

- Hayman, Ronald. (1975). Harold Pinter. London: Heinemann Educational Book, Ltd.

- John Elson. (1976). Post war British Theater .London: Routledge \& Kegan Paul.

- Knight, G. Wilson. (1963).The Kitchen Sink. Encounter.

- Kohzadi, Hamedreza. (2012). Alienation in Harold Pinter's The Room. Journal of Basic and Applied Scientific Research. Text Road Publication.

- Kreps, Barbra, (1979),"Time and Harold Pinter's Possible Realities: Art as Life, and Vice versa, "Modern Drama 22, no.1.

- Pesta, John. (1967). Pinter's Usurpers, Drama Survey, VI Spring.

- Pesta, John. (1972). Pinter's Usurpers, "in Pinter: a Collection of Critical Essay. (Englewood Cliffs, N.J.: Prentice-Hall, Inc.

- Quigley, Austin. (1975).The Pinter's Problems. Princeton, N.J.: Princeton University Press.

- R. F. Storch, Harold Pinter's Happy Families, in Pinter's A Collection of Critical Essays.

- Ruby Cohn, The world of Harold Pinter, in Pinter: A Collection of Critical Essays. Arthur Ganz, p. 80) Englewood Cliffs. N.J. Princeton-Hall, Inc., 1972.

- Sanders, Andrew, (2004), The Short Oxford History of English Literature. 3rd ed. London: Oxford University Press,

\section{INTERNATIONAL JOURNAL OF RESEARCH IN SOCIAL SCIENCES AND HUMANITIES}


- Sherman, Joseph, ed. (1970), Contrast in Drama. London: Edward Arnold.

- Trussler, Simon. (1973). The Plays of Harold Pinter: an Assessment (Victor Gollancz Ltd.

- Wager, Walter, ed. (1969). The Playwright Speak. Longman, Green and Co. LTD.,

- Wellwarth, George E. (1964). The theater of Protest and Paradox. New York: New York University Press.

- Wellworth, George E. (1971).The Theatre of Protest and Paradox. New York: New York UP. 